\title{
Plasticity in the Nervous System of Adult Hydra. III. Conversion of Neurons to Expression of a Vasopressin-like Immunoreactivity Depends on Axial Location
}

\author{
Osamu Koizumia and Hans R. Bode \\ Developmental Biology Center and Department of Developmental and Cell Biology, University of California at Irvine, Irvine, \\ California 92717
}

\begin{abstract}
The nervous system of hydra consists of a nerve net that extends throughout the animal. Becasue of the tissue dynamics of hydra, the nerve net is in a steady state of production and loss of neurons. Neurons are continuously produced in the body column and are constantly lost by sloughing at the extremities and into developing buds. Consequently, every neuron is continuously displaced towards an extremity. A subset of the neurons of the nerve net, termed vasopressin-like-immunoreactive (VLI ${ }^{+}$) neurons, has been identified with an antiserum against vasopressin. This subset has a specific regional distribution in that it is found in the head, peduncle, and foot of an adult hydra. The VLI+ neurons in the head and peduncle are ganglion cells, while those in the foot include a newly described sensory cell. How is the regional distribution of the subset maintained when every neuron is continually changing location? Removal of the neuron precursors indicates the VLI+ neurons can arise by conversion from VLI- neurons of the body column. In the normal animal they probably arise by conversion as well as by differentiation. Conversion of $\mathrm{VLI}^{-}$to $\mathrm{VLI}^{+}$neurons is due to a change in axial position, or region, instead of a maturation process.
\end{abstract}

The freshwater coelenterate hydra has a simple body plan. It is basically a tube made up of two epithelial layers, with a head at one end and a foot at the other. Concomitantly, the nervous system is also simple. It consists of a loose net of neurons that extends throughout the animal (e.g., Hadzi, 1909; Lentz and Barnett, 1965) and is intermingled among the epithelial cells of both layers. Morphologically, the nerve cells making up the net are bipolar and multipolar neurons (e.g., Epp and Tardent, 1978), which are referred to as ganglion cells (e.g., Kinnamon and Westfall, 1982). In addition, there are sensory neurons whose neurites connect these cells with the nerve net.

The net is composed of a mosaic of subsets of neuron phenotypes, each with a particular regional distribution. Some of these subsets have been defined in histological and ultrastruc-

\footnotetext{
Received Aug. 7, 1990; revised Dec. 11, 1990; accepted Jan. 23, 1991.

We thank Ron Meyer and Douglas Fisher for their critical reading of the manuscript. This research was supported by NIH Grants HD 16440 and HD 08086 to H.R.B. and by overseas grants from the Japanese Ministry of Education and Science, and Fukuoka Prefecture to O.K.

Correspondence should be addressed to Hans R. Bode, Developmental Biology Center, University of California at Irvine, Irvine, CA 92717.

a Present address: Physiological Laboratory, Department of Science, Fukuoka Women's University, Higashi-ku, Fukuoka, 813 Japan.

Copyright (C) 1991 Society for Neuroscience 0270-6474/91/112011-10\$03.00/0
}

tural studies, notably, distributions of multipolar and bipolar neurons as well as sensory cells (Davis, 1972; Epp and Tardent, 1978; Westfall and Kinnamon, 1978; Kinnamon and Westfall, 1982). However, the use of antisera against neuropeptides and monoclonal antibodies that recognize neurons has provided the clearest demonstration of these subsets and their individual regional locations (Grimmelikhuijzen et al., 1980, 1981a-c, 1982a,b; Dunne et al., 1985; Koizumi and Bode, 1986; Yaross et al., 1986; Koizumi et al., 1988). The number of subsets is still unclear, because it is unlikely that the antibodies accumulated so far define all the subsets.

An interesting aspect of the nerve net is that it is in a steady statc of production and loss of ncurons (Bode et al., 1986, 1988). This is a consequence of the tissue dynamics of the animal. The two epithelial layers are in a steady state in which production of cells in the body column is balanced by the loss of cells at the extremities by sloughing, as well as by budding, the asexual mode of reproduction (Campbell, 1967a,b; David and Campbell, 1972; Otto and Campbell, 1977). A consequence is that every epithelial cell is continuously displaced towards either head or foot and is eventually lost.

The nerve net is in a similar state. Because the processes of the neurons are intertwined among the epithelial cells, each neuron is displaced towards an extremity along with, and at the same rate as, the epithelial cells. Thus, neurons are also continuously lost with the epithelial tissue by sloughing at the extremities or into buds (Yaross et al., 1986). The steady state is maintained as new neurons arise by differentiation constantly and are added to the net throughout most of the animal (David and Gierer, 1974).

The continuous change of location of each neuron coupled with the constant pattern of the mosaic of subsets of neurons poses a problem. How is the mosaic of subsets maintained in the context of constant change of location? Earlier studies have shown that there are two means to achieve this end. In one, the epidermal sensory cells of the tentacles are maintained by new differentiation (Yaross et al., 1986). In the other, the epidermal sensory cells of the hypostome, and a subset of the ganglion cells of the tentacles, are maintained at least in part by the conversion of the phenotype of the neuron as it is displaced from one region to another (Koizumi and Bode, 1986; Koizumi et al., 1988).

It is of some importance for an understanding of the extent of the plasticity of neuron phenotype in hydra to determine the fraction of subsets that can arise by conversion. We report herc the results of the examination of a subset of neurons identified 


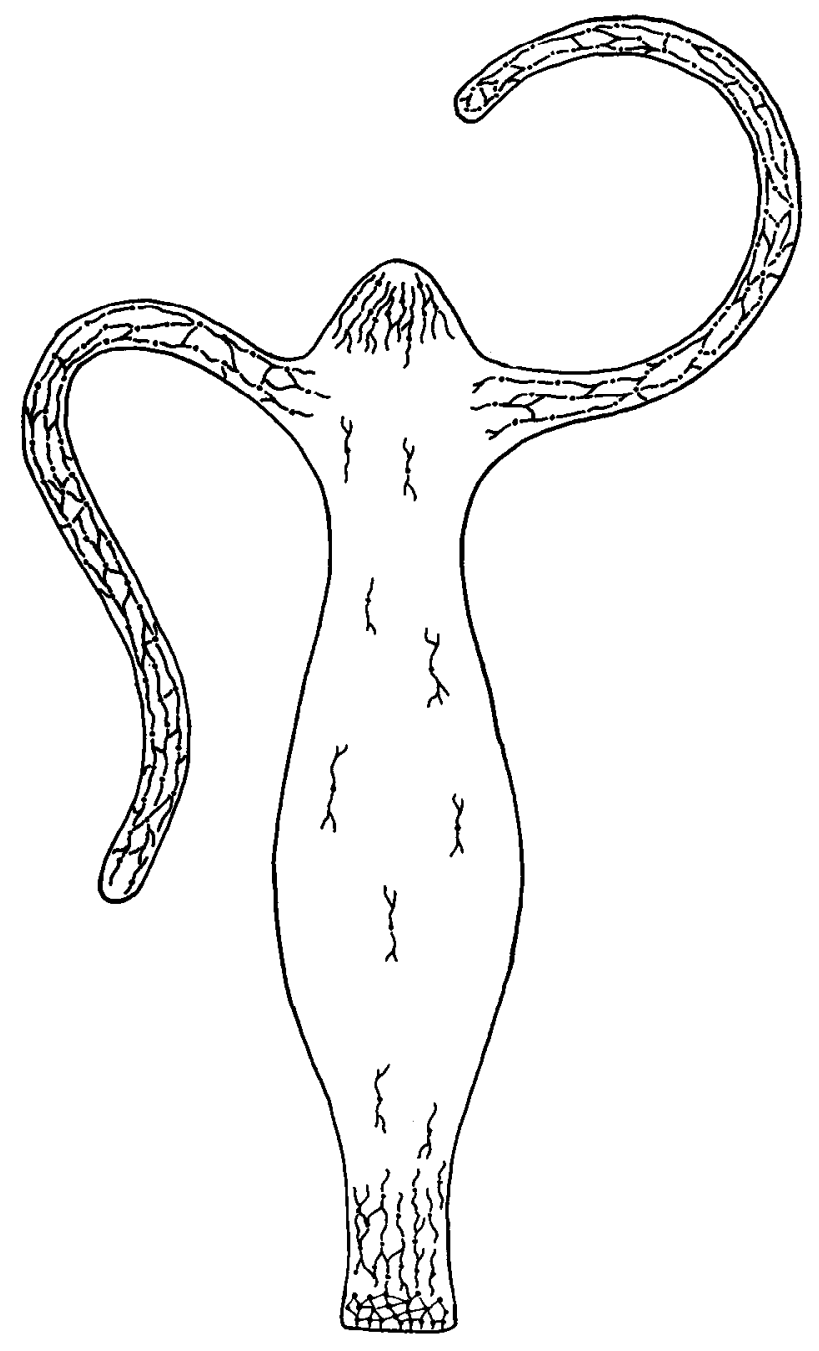

Figure 1. Schematic of hydra indicating the regions and the distribution of neurons expressing VLI.

with an antiserum against the neuropeptide vasopressin. This subset arises by conversion in both the head and the foot adding to the number of subsets of neurons that are only metastably differentiated. Further, vasopressin recognizes a population of sensory neurons in the foot that has not bcen prcviously dcscribed.

\section{Materials and Methods}

Animal culture and histological methods. Hydra vulgaris were used for most experiments, and Hydra oligactis for a few. Hydra vulgaris (formerly Hydra attenuata) were originally obtained from Pierre Tardent (Zurich) and have been in continuous culture at the University of California at Irvine since 1981 . The Hydra oligactis are a Swiss male strain kindly provided by Lynne Littlefield, who has maintained them at the University of California at Irvine since 1981. Stock cultures of both species were maintained as described by Dunne et al. (1985). Animals were starved $24 \mathrm{hr}$ before use.

Procedures used for the elimination of interstitial cells and neuron differentiation intermediates with nitrogen mustard or hydroxyurea, as well as the toluidine blue staining method for determining the number of interstitial cells remaining after treatment with nitrogen mustard or hydroxyurea, have been described previously (Koizumi and Bode, 1986; Koizumi et al., 1988).

Immunocytochemistry. The procedure for staining whole-mounts of hydra with an antiserum against vasopressin was adapted from the procedure described by Grimmelikjuijzen et al. (1982a). Animals were relaxed in a $2 \%$ urethane (Sigma) solution in hydra medium (Dunne et al., 1985) for 1-3 min. Thereafter, they were fixed in $10 \%$ formalin for 30 min followed by a 20 -min fixation in Lavdovsky's fixative (Dunne et al., 1985). Then they were washed twice in PBS and exposed to blocking serum (Dunne et al., 1985) overnight. These animals were exposed to an anti-vasopressin antiserum (Immunonuclear) diluted $400 \times$ in PBS containing $0.3 \%$ Triton, $2 \%$ neonatal calf serum (Irvine Scientific), and $0.1 \%$ sodium azide for $45 \mathrm{~min}$, and then washed $30 \mathrm{~min}$ with PBS. The second stage was a $50 \times$ dilution of a biotinylated goat antirabbit IgG (Vector) in PBS containing $0.05 \%$ Tween 20 and $0.1 \%$ sodium azide (PBST) for $30 \mathrm{~min}$. Following a 30-min PBS wash, they were incubated with a $10 \times$ dilution of florescein isothiocyanate-streptavidin (Zymed) in PBST for 30 min. After a final 30-min wash in PBS, they were mounted in $70 \%$ glycerol in $0.1 \mathrm{M}$ Tris $(\mathrm{pH}, 9.0)$ containing $5 \%$ $n$-propyl gallate and observed with a Zeiss photomicroscope equipped with fluorescent optics.

To be sure that the antiserum recognized vasopressin or a related molecule, the antiserum was preincubated overnight with $1,10,100 \mu \mathrm{g}$ of vasopressin and then subsequently used to stain whole-mounts. At all three concentrations, the staining was abolished.

\section{Results}

Regional distribution and phenotype of neurons expressing a vasopressin-like immunoreactivity

The only cell types that stain with an antiserum against vasopressin in Hydra vulgaris are neurons. Grimmelikhuijzen et al. (1982a) had shown this in histological sections, and we have confirmed and extended their findings with immunocytochemistry on whole-mounts. Because the antiserum binds to vasopressin, or more accurately, some neurons in hydra express a vasopressin-like immunoreactivity (VLI), neurons that stain with the serum will be referred to as $\mathrm{VLI}^{+}$.

$\mathrm{VLI}^{+}$neurons are found in the ectoderm of specific regions of the animal. They occur in large numbers in the head, in the foot, and in the lower peduncle, which is the basal eighth of the body column. Only very small numbers of $\mathrm{VLI}^{+}$neurons are found in the rest of the body column. A summary of the regional distribution is shown in Figure 1. It is similar to that described by Grimmelikhuijzen et al. (1982a).

In the head, $\mathrm{VLI}^{+}$neurons are found both in the hypostome (Fig. 2a), which is the dome of tissue at the apex of the animal, and in the ring of tentacles directly below the hypostome (Fig. $2 b$ ). In these two regions as well as in the lower peduncle (Fig. $2 c$ ), the processes emanating from the cell bodies of $\mathrm{VLI}^{+}$neurons each have a preferred orientation. In the hypostome, the processes are oriented in a radial manner from the apex down the sides of the dome (Fig. $2 a$ ), while in the tentacles most of the processes are parallel to the tentacle length (Fig. $2 b$ ). Those in the lower peduncle are parallel to the body axis (Fig. 2c). The neurites of the very large number of $\mathrm{VLI}^{+}$neurons in the basal disk have no discernible orientation, but instead exhibit a netlike pattern (Fig. 2d).

The $\mathrm{VLI}^{+}$neurons are of two types. All of those in the hypostome, in the tentacles, and in the lower peduncle are ganglion cells. They are both bipolar and multipolar neurons and are characterized by neurites that are often branched (Fig. 3a). Their cell bodies are located near the base of the ectoderm close to the mesoglea, the basement membrane separating the ectoderm and endoderm (e.g., Diehl and Burnett, 1964; Lentz and Barnett, 1965). Figure $3 b$ is a tangential view of such a neuron in the peduncle.

Some of the $\mathrm{VLI}^{+}$neurons in the basal disk are not ganglion cells. They are sensory cclls, whose most prominent feature is a long stained sensory hair that extends from near the base of 

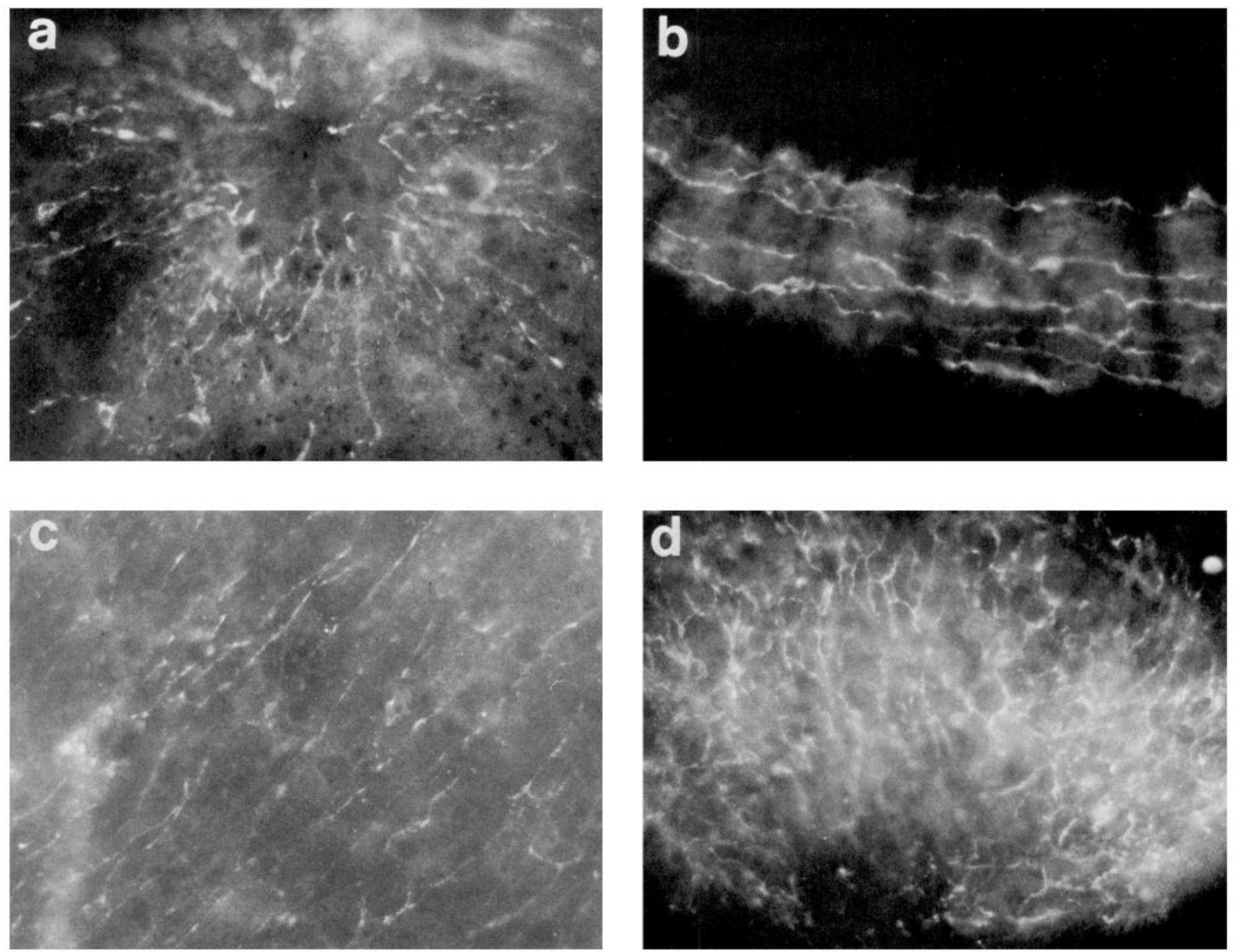

Figure 2. $\mathrm{VLI}^{+}$neurons in several regions of adult hydra. In this and all subsequent figures, the $\mathrm{VLI}^{+}$neurons were visualized with immunocytochemistry in whole-mounts. $a$, Hypostome: apex is the area devoid of stained neurons in the upper central area. $b$, Tentacle: mid-tentacle region is running left to right. c, Peduncle: the body axis runs from lower left to upper right. $d$, Basal disk: bottom of basal disk is at the bottom. Magnification, $370 \times$.

the ectoderm to the apical surface (Fig. 3c). The cell body, which is not as brightly stained, is oval in shape and located near the base of the ectoderm.

Staining of a second species, Hydra oligactis, showed the same pattern of staining as well as the same stained neuron phenotypes in each region (data not shown).

\section{$V L I^{+}$neurons can arise by conversion from $\mathrm{VLI}^{-}$neurons}

In the context of the dynamic nerve net of hydra, in which every neuron is continuously displaced towards one of the extremities, the constant spatial pattern of the $\mathrm{VLI}^{+}$subset could arise by new differentiation of $\mathrm{VLI}^{+}$neurons or by conversion of $\mathrm{VLI}^{-}$ to $\mathrm{VLI}^{+}$neurons. This possibility was tested directly by eliminating the neuron precursors from the animal and subsequently determining if there were temporal changes in the regional distribution of the $\mathrm{VLI}^{+}$subset in two circumstances. The general scheme of the experiment is shown in Figure $4 A$.

Neurons arise by differentiation from stem cells among the interstitial cells (David and Murphy, 1977). Because all interstitial cells are in the mitotic cycle (Campbell and David, 1974), this population of cells can be eliminated by treating animals with nitrogen mustard (Diehl and Burnett, 1964) or with hydroxyurea (Sacks and Davis, 1979). The treatment also eliminates all neuron-differentiation intermediates. Two groups of animals were treated, one with hydroxyurea, and the other with nitrogen mustard. To be sure that each of the two treatments was effective, some of the animals of each group were stained as whole-mounts with toluidine blue, and the number of remaining intersitial cells was determined. A few days after the end of treatment ( $3 \mathrm{~d}$ for hydroxyurea, $7 \mathrm{~d}$ for nitrogen mustard), most of the animals were devoid of interstitial cells (Table 1). By the time they were analyzed for $\mathrm{VLI}^{+}$neurons, almost all of the animals were devoid of interstitial cells.

Some of the treated animals were stained for $\mathrm{VLI}^{+}$neurons 12-13 d after assaying for the absence of interstitial cells in hydroxyurea-treated animals, or similarly, 9-12 d for the nitrogen mustard-treated animals. In both cases the spatial distribution of $\mathrm{VLI}^{+}$neurons in all treated animals examined was the same as in normal animals. There were large numbers of $\mathrm{VLI}^{+}$ neurons in the lower peduncle (Fig. 5c) and foot (Fig. 5d) com- 

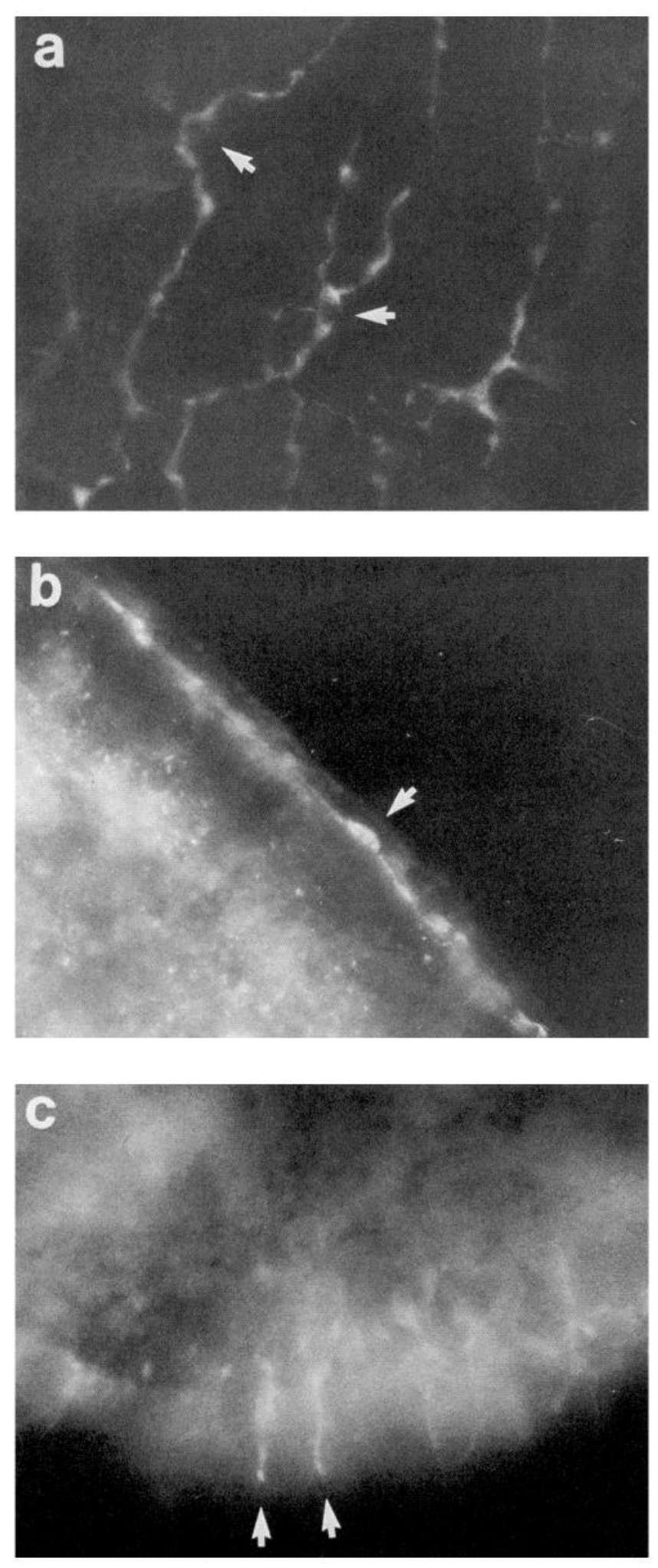

Figure 3. Phenotypes of $\mathrm{VLI}^{+}$neurons. $a$, Face-on view of ganglion cells, which are bipolar and multipolar neurons. Arrows indicate cell body. $b$, Tangential view of a ganglion cell in the peduncle. The arrow points to the cell body, which is located at the base of the ectoderm; the arrow tip is located at the apical surface of the ectoderm. $c$, Tangential view of the ectoderm of the bottom of the basal disk. Arrows point to the stained processes of $\mathrm{VLI}^{+}$sensory cells. Magnification, $560 \times$. pared to the far fewer numbers in the body column (Fig. 6e). Many of the $\mathrm{VLI}^{+}$neurons had processes extending from the base to the apex of the ectoderm, indicating that they were sensory cells (Fig. 5e). The numbers of $\mathrm{VLI}^{+}$neurons in the hypostome (Fig. $5 a$ ) and tentacles (Fig. $5 b$ ) were substantial and more than those found in the body column, though less than those found in these regions in normal animals (Fig. 2a,b).

Because tissue displacement continues despite either treatment (Yaross et al., 1986) and the tissue in the tentacles, lower peduncle, and foot turned over completely in this period of time (Yaross et al., 1986; H. R. Bode and L. Gee, unpublished observations), the $\mathrm{VLI}^{+}$neurons observed in these regions were not those present before the beginning of treatment. Instead, they most likely arose by conversion from $\mathrm{VLI}^{-}$neurons for two reasons: (1) because most of the animals were devoid of neuron intermediates shortly after the end of the treatment, they could not have arisen by differentiation; and (2) there are too few $\mathrm{VLI}^{+}$ neurons in the body column for those in the extremities to have arisen by displacement from the body column.

The conversion of $\mathrm{VLI}^{-}$to $\mathrm{VLI}^{+}$neurons can be demonstrated more directly by making use of hydra's extensive capacity for regeneration. Decapitated animals regenerate a head by reorganizing the apical end of the body column into a head. This process does not require cell division (Hicklin and Wolpert, 1973; Cummings and Bode, 1984) and, in effect, abruptly converts epithelial cells and neurons of the body column into those of the head. Removing the foot results in foot regeneration with processes analogous to head regeneration. By removing the neuron precursors and removing either the head or the foot of the animal, one can determine if the regenerated extremities contain substantial numbers of $\mathrm{VLI}^{+}$neurons.

The experiment is shown in Figure 4, $B$ and $C$. After determining that the neuron precursors had been eliminated in a majority of the treated animals, either the head or the foot was removed from groups of animals. The missing extremities were allowed to regenerate, and the animals were then stained with the anti-vasopressin antiserum.

The results are most dramatic for the lower peduncle and basal disk. More than $90 \%$ of the regenerated feet and lower peduncles contained $\mathrm{VLI}^{+}$neurons (Table 1). Large numbers of $\mathrm{VLI}^{+}$neurons appeared both in the foot and in the lower peduncle (Fig. $6 c$ ). Further, many of the $\mathrm{VLI}^{+}$neurons in the ectoderm of the regenerated foot were sensory cells (Fig. 6d). Conversion of neuron phenotype also took place during head regeneration, though the number of $\mathrm{VLI}^{+}$neurons formed was less than at the basal end. More than $80 \%$ of the heads of hydroxyurea-treated animals, and $>95 \%$ of the heads of nitrogen mustard-treated animals, contained $\mathrm{VLI}^{+}$neurons (Table 1). Examples are shown in Figure $6 a$ for the hypostome and Figure $6 b$ for the tentacles.

Because most of these animals were devoid of neuron precursors, the majority of the $\mathrm{VLI}^{+}$neurons could not have arisen by differentiation. Thus, they most likely arose by conversion from $\mathrm{VLI}^{-}$neurons as the regenerating apical end formed a head and while the basal end of the body column was reorganized into the foot and lower peduncle. Because the body column contains a very small number of $\mathrm{VLI}^{+}$neurons, a few could have been part of the body column that was displaced into either head or foot during the reorganization.

To determine the fractions of $\mathrm{VLI}^{+}$neurons in the head due to displacement and conversion, respectively, the experiment was repeated with the variation that hydra were treated with 


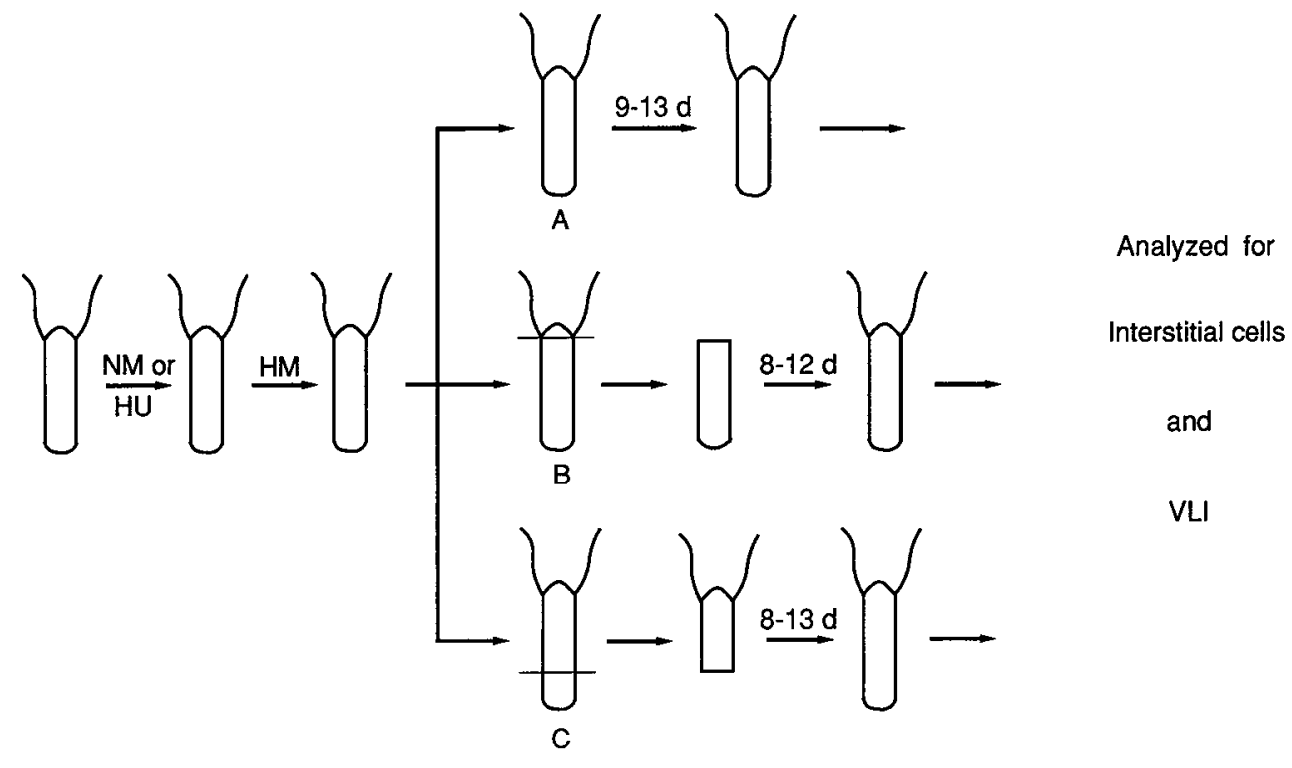

Figure 4. Experimental procedure used to determine if $\mathrm{VLI}^{+}$neurons can arise by conversion of $\mathrm{VLI}^{-}$neurons of the body column. $A$, Control animals. $B$, Decapitated animals. $C$, Animals in which the peduncle and foot have been removed. See text for details. $N M$, nitrogen mustard; $H U$, hydroxyurea; $H M$, hydra medium. The indicated times, in days, are the times between the initial analysis for interstitial cells and the final analysis for interstitial cells and for $\mathrm{VLI}^{+}$neurons. nitrogen mustard. After determining that the interstitial cells had been eliminated, animals were decapitated. Half were stained immediately for $\mathrm{VLI}^{+}$neurons, while the other half were allowed to regenerate heads (which occurred in 8-12 d) and then were stained with the antiserum. The number of $\mathrm{VLI}^{+}$neurons was counted in the upper quarter of the freshly decapitated animals, as wcll as in the head of the regenerated animals. The regenerated heads contained about twice as many $\mathrm{VLI}^{+}$neurons as the upper quarter of the body column (Table 2). The differences are probably greater because the head usually regenerates from the apical sixth of the column (Bode and Bode, 1980). Hence, the numbers of $\mathrm{VLI}^{+}$neurons that became part of the head due to tissue reorganization and displacement are closer to two-thirds of the values measured in the apical quarter. Thus, at least half of the $\mathrm{VLI}^{+}$neurons in the regenerated head arose by conversion of $\mathrm{VLI}^{-}$to $\mathrm{VLI}^{+}$neurons.

Conversion of $\mathrm{VLI}^{-}$neurons to $\mathrm{VLI}^{+}$neurons is a position-dependent effect

The conversion of $\mathrm{VLI}^{-}$neurons to $\mathrm{VLI}^{+}$neurons as they are displaced from the body column into an extremity suggests the $\mathrm{VLI}^{-}$neurons are responding to a cue associated with their new position and consequently undergoing conversion. This has clearly been demonstrated for the subset of neurons in hydra defined by an antiserum against FMRFamide (Koizumi and Bode, 1986). An equally plausible explanation is that the conversion is a result of maturation of some neurons. They would undergo this conversion simply as a consequence of a temporal component of their development.

To determine if the effect was a position-dependent process, a regeneration experiment was carried out. Under the conditions in which the stock cultures are maintained, the tissue in the upper quarter of the gastric region (that part of the body column between the head and the budding zone) of $H$. oligactis is normally displaced into the head, while the rest of the body column is displaced in a basal direction into buds or toward the foot. Thus, neurons in the upper quarter would never end up in the foot. Consequently, one would not expect these neurons to develop into the sensory cells of the foot by a maturation process.

Animals were treated with nitrogen mustard to eliminate the interstitial cells, and then bisected in the gastric region a little less than one-quarter of the distance from the head. The upper part was allowed to regenerate a foot and stained with the antiserum; 14 of 16 animals regenerated feet, and of these, 12 of

Table 1. VLI in regenerates of interstitial cell-depleted $H$. vulgaris

\begin{tabular}{|c|c|c|c|c|c|c|c|c|c|c|}
\hline \multirow[b]{3}{*}{ Treatment } & \multirow[b]{3}{*}{ Regenerate } & \multicolumn{4}{|c|}{$\begin{array}{l}\text { Fraction of animals } \\
\text { without } \\
\text { interstitial cells }\end{array}$} & \multicolumn{5}{|c|}{$\begin{array}{l}\text { Fraction of regenerates } \\
\text { with } \mathrm{VLI}^{+} \text {neurons (\%) }\end{array}$} \\
\hline & & \multicolumn{2}{|c|}{$\overline{\text { Initial }}$} & \multicolumn{2}{|c|}{ Final } & \multirow[b]{2}{*}{$N$} & \multirow{2}{*}{$\begin{array}{l}\text { Tent- } \\
\text { acle }\end{array}$} & \multirow{2}{*}{$\begin{array}{l}\text { Hypo- } \\
\text { some }\end{array}$} & \multirow{2}{*}{$\begin{array}{l}\text { Ped- } \\
\text { uncle }\end{array}$} & \multirow{2}{*}{$\begin{array}{l}\text { Basal } \\
\text { disk }\end{array}$} \\
\hline & & $N$ & $\%$ & $N$ & $\%$ & & & & & \\
\hline Nitrogen mustard & $\begin{array}{l}\text { Head } \\
\text { Peduncle and foot } \\
\text { Control }\end{array}$ & 11 & 82 & $\begin{array}{l}22 \\
41\end{array}$ & $\begin{array}{l}100 \\
100\end{array}$ & $\begin{array}{r}38 \\
33 \\
9\end{array}$ & $\begin{array}{l}100 \\
100 \\
100\end{array}$ & $\begin{array}{r}97 \\
100 \\
89\end{array}$ & $\begin{array}{r}100 \\
97 \\
100\end{array}$ & $\begin{array}{r}97 \\
94 \\
100\end{array}$ \\
\hline Hydroxyurea & $\begin{array}{l}\text { Head } \\
\text { Peduncle and foot } \\
\text { Control }\end{array}$ & 33 & 67 & $\begin{array}{l}15 \\
29 \\
21\end{array}$ & $\begin{array}{r}93 \\
100 \\
100\end{array}$ & $\begin{array}{l}12 \\
15 \\
18\end{array}$ & $\begin{array}{r}83 \\
100 \\
100\end{array}$ & $\begin{array}{r}92 \\
100 \\
94\end{array}$ & $\begin{array}{r}100 \\
100 \\
94\end{array}$ & $\begin{array}{r}100 \\
93 \\
88\end{array}$ \\
\hline
\end{tabular}

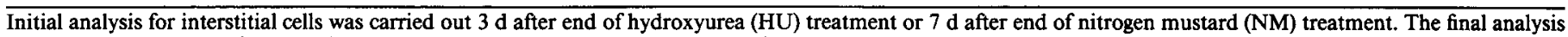

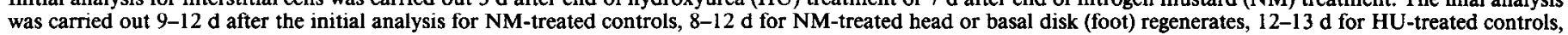

$12 \mathrm{~d}$ for $\mathrm{HU}$-treated head regenerates, and $13 \mathrm{~d}$ for $\mathrm{HU}$-treated foot regenerates. $N$, number of samples. 

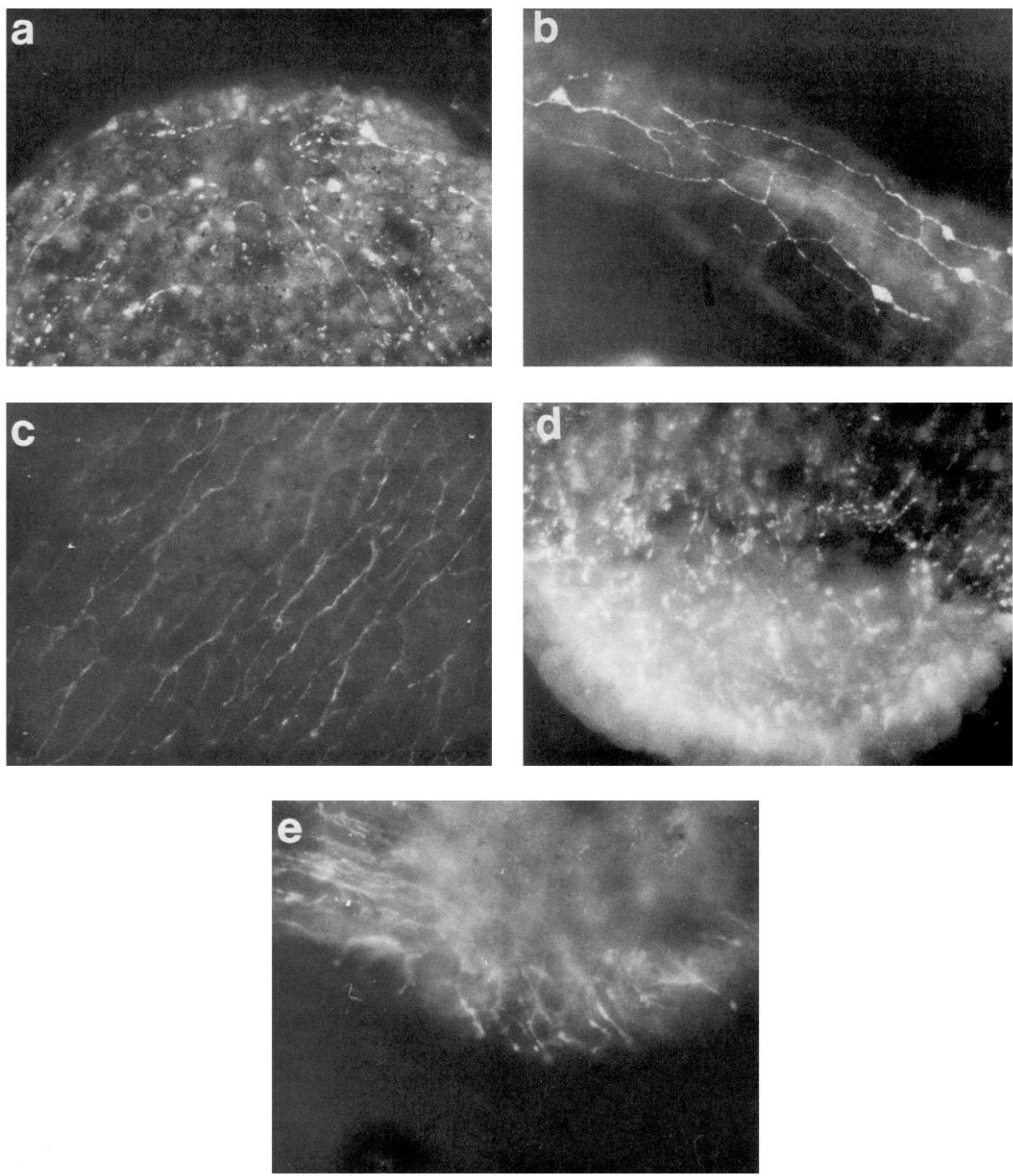

Figure 5. Maintenance of $\mathrm{VLI}^{+}$neurons in several regions in the absence of neuron differentiation from interstitial cells. Animals were stained 9-13 d after analysis indicated the absence of interstitial cells. $a$, Hypostome: apex is in the upper central area. $b$, Tentacle. $c$, Peduncle: body axis runs from lower left to upper right. $d$, Basal disk: bottom of the basal disk is at the bottom. $e$, Ectoderm of bottom of basal disk showing stained processes of sensory cells. Magnification: $a-d, 370 \times ; e, 600 \times$. 

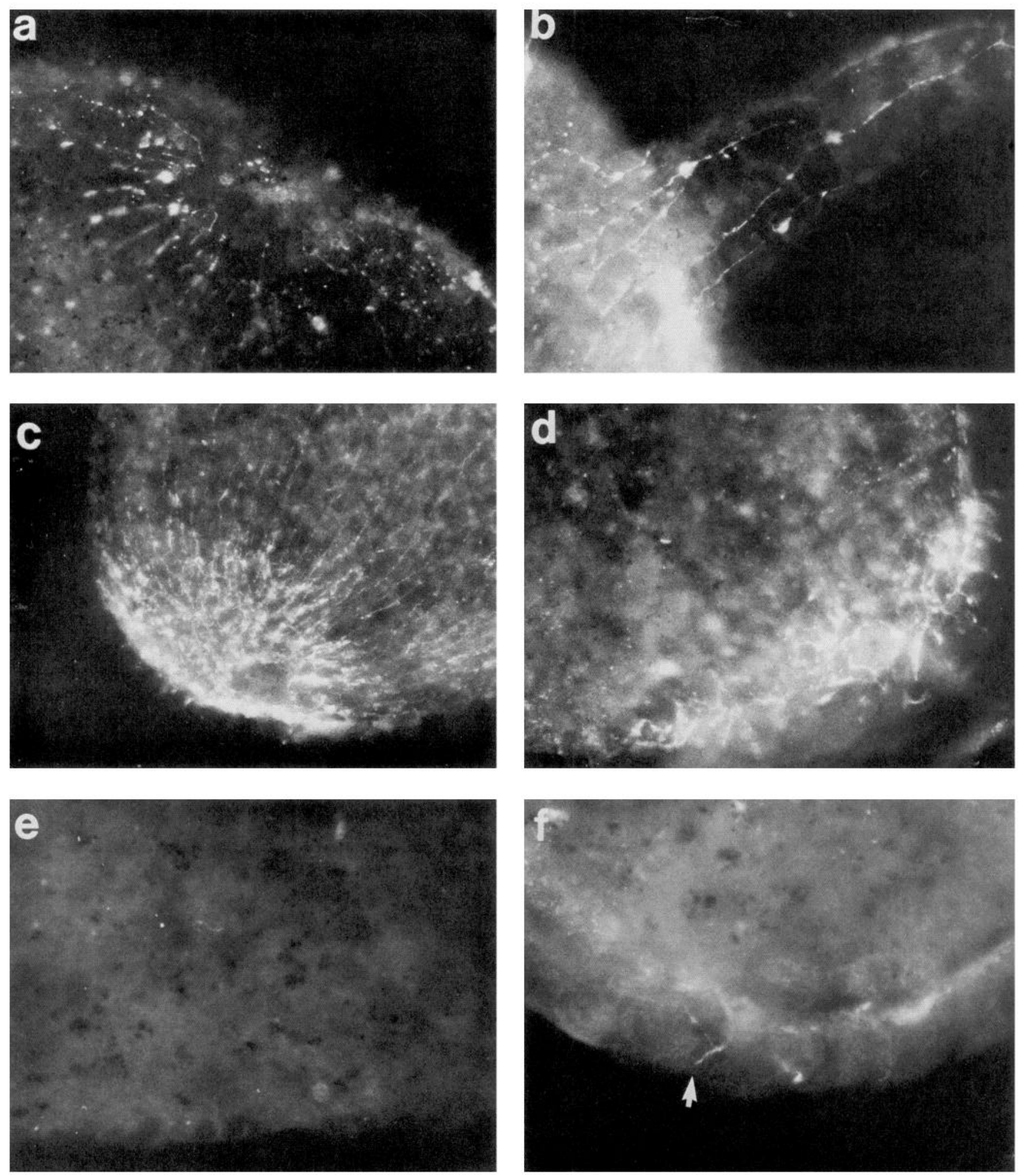

Figure 6. $\mathrm{VLI}^{+}$neurons in regenerated heads and feet of animals devoid of interstitial cells. $a$, Hypostome: apex is in the center. $b$, Tentacle emerging from head at left. $c$, Basal disk and lower peduncle. $d$, Tangential view of basal disk: ectoderm of bottom of basal disk with stained sensory cells is toward the lower right. $e$, Basal end of an animal shortly after bisection in the upper quarter of the gastric region of the body column. $f$, Regenerating foot of an animal bisected as in $e$ with a few stained sensory cells. Magnification: $a$ and $b, 370 \times ; c, 190 \times ; d, 45) \times ; e$ and $f, 600 \times$. 
Table 2. Comparison of the number of $\mathrm{VLI}^{+}$neurons in the upper body column and in regenerated heads of $H$. vulgaris

\begin{tabular}{llllll} 
& \multicolumn{2}{l}{$\begin{array}{l}\text { Upper quarter of the } \\
\text { body column }\end{array}$} & & \multicolumn{2}{l}{$\begin{array}{l}\text { Regeneraled } \\
\text { head }\end{array}$} \\
\cline { 2 - 3 } \cline { 5 - 6 } Experiment & $N$ & $\begin{array}{l}\mathrm{VLI}^{+} \\
\text {neurons }\end{array}$ & & $N$ & $\begin{array}{l}\mathrm{VLI}^{+} \\
\text {neurons }\end{array}$ \\
\hline 1 & 20 & $8.4 \pm 5.4$ & & 25 & $18.0 \pm 6.6$ \\
2 & 21 & $11.3 \pm 4.2$ & & 30 & $17.8 \pm 6.6$
\end{tabular}

$N$ is number of samples; the error is the SD. Using the $t$ test, the two means in both experiments were shown to be significantly different $(p<0.01)$.

14 contained $\mathrm{VLI}^{+}$foot sensory cells. An example is shown in Figure $6 f$. Because neurons of the upper quarter of the gastric region would not normally form this type of neuron during the course of their development or history, the formation of the neuron is due to a position-dependent effect and not to a maturation process.

\section{Discussion}

Plasticity of neuron phenotype in hydra

That the phenotype of a neuron can be plastic, and hence a neuron's differentiated state only metastable, is a phenomenon for which examples have been accumulating. Changes have been induced experimentally in vitro (e.g., Patterson and Chun, 1977) and have been observed at specific stages of development in a number of species (e.g., Sulston and Horvitz, 1977; Alley and Barnes, 1983; Landis and Keefe, 1983; Thorn and Truman, 1989) as well as in adults (e.g., Katz et al., 1983). Similar changes have also been observed in hydra (Koizumi and Bode, 1986; Koizumi et al., 1988).

Unlike other animals, these changes occur continuously in the adult hydra, and probably occur in many types of its neurons. This is undoubtedly due to the tissue dynamics of the animal, which result in the nervous system being in a steady state of production and loss of neurons (Bode et al., 1986, 1988). A consequence of this condition is that every neuron is constantly changing its location in the animal by displacement.

An important question concerns how widespread neuron phcnotype plasticity is in this nervous system. Are all neurons metastably differentiated, or only some of them? Of the subsets, each defined by binding to a specific antibody, that have been examined so far, two are plastic and one is not. A subset of the epidermal sensory cells restricted to the tentacles in Hydra ollgactis arises only by differentiation and cannot be replaced by conversion (Yaross et al., 1986). In contrast, neurons exhibiting FMRFamide-like immunoreactivity $\left(\mathrm{FLI}^{+}\right)$in the head and lower peduncle of Hydra attenuata can arise by conversion from neurons that do not express this activity (Koizumi and Bode, 1986). Furthermore, a subset of ganglion cells of the hypostome in Hydra attenuata defined by a monoclonal antibody is converted into a subset of epidermal sensory neurons restricted to the hypostome and defined by a second monoclonal antibody (Koizumi et al., 1988).

The results presented here add another subset of neurons whose phenotype can change. Some of the $\mathrm{VLI}^{-}$neurons displaced from the upper body column into the head, or from the lower middle body column into the peduncle, are converted into $\mathrm{VLI}^{+}$neurons. All of these neurons are bipolar and multipolar ganglion cells. This conversion involves the appearance of a VPI.
A second conversion occurs that involves more widespread changes. When either $\mathrm{VLI}^{-}$or $\mathrm{VLI}^{+}$ganglion cells of the lower peduncle are displaced onto the basal disk, many of them are converted into a $\mathrm{VLI}^{+}$sensory cell type in the ectoderm that is found only in the foot. This conversion involves a number of changes. Most prominent among them is the elaboration of a cilium, which implies the synthesis of a number of molecules necessary for its construction.

This foot sensory cell differs from the epidermal sensory cell of the head and the sensory cell of the endoderm in two ways. The latter have elongated cell bodies and relatively short cilia (Epp and Tardent, 1978; Westfall and Kinnamon, 1978; Westfall and Rogers, 1990), whereas the foot sensory cell has an oval cell body and a cilium that extends from the basal side to the apical edge of the ectoderm. Although Grimmelikhuijzen et al. (1982a) described $\mathrm{VLI}^{+}$processes running from the base to the apex of the cilium, this article presents, to our knowledge, the first observation of sensory cells in the foot.

After hydroxyurea or nitrogen mustard treatment, only neurons and epithelial cells remain in the ectoderm. Thus, it is possible that the $\mathrm{VLI}^{+}$neurons found in the ectoderm arose from epithelial cells instcad of from $\mathrm{VLI}^{-}$neurons. This is highly unlikely for the following reasons: hydra consisting only of epithelial cells and completely devoid of neurons as well as all other cell types of the interstitial cell system have been maintained for periods of 1-6 yr on a number of occasions (e.g., Marcum and Campbell, 1978; Heimfeld and Bode, 1985; Littlefield and Bode, 1986). The epithelial cells continue to proliferate, and the animals reproduce quite normally. Never have neurons been observed to reappear in such animals, indicating that conversion of epithelial cells into neurons does not occur. Such neuron-free tissue is permissive for neuron differentiation because reintroduction of interstitial cells promptly leads to neuron differentiation from the interstitial cells (e.g., Heimfeld and Bode, 1984).

\section{Changes in VLI expression involve a position-dependent process}

The alteration of neuron phenotype that occurs in vivo after experimental manipulation is often clcarly attributable to changes in the environment. This has been shown for neurons whose location in the embryo or animal has been experimentally altered (Coulombe and Bronner-Fraser, 1986; Schotzinger and Landis, 1988) or whose target tissue has been altered (e.g., Loer and Kristan, 1989a,b), or if the precursor does not reach the appropriate location (Copenhaver and Taghert, 1988, 1989).

The simplest explanation for the position-dependent changes in hydra observed here and previously (Koizumi and Bode, 1986; Koizumi et al., 1988) is also that they respond to a new set of local environmental cues when they are displaced from one region to another. Two experiments in which one can manipulate the extremity into which a neuron is displaced provide very strong evidence for this viewpoint.

When animals are bisected in the middle of the body column, the lower half regenerates a head at the apical end. The tissue that formed the head in the regenerate is normally displaced towards the foot, but never towards the head, in intact animals. Among the neurons of the regenerated head are epidermal sensory neurons, which are found only in the head (Koizumi and Bode, 1986). Thus, neurons destined to be part of the foot formed neurons specific for the head.

Conversely, when an animal is bisected close to the head, the 
basal end of the upper half forms a foot. Normally, this footforming tissue would be displaced into the head. $\mathrm{VLI}^{+}$foot sensory cells were found in such a regenerating foot. Again, neurons destined to be part of the head formed foot-specific neurons.

Such changes of displacement direction can occur in normal animals. Displacement of tissue in apical and basal directions implies a region in the body column in which little or no displacement occurs in either direction. The presence of this region, the stationary zone, has been demonstrated (Campbell, 1967b; Otto and Campbell, 1977). The axial location of the stationary zone depends on the rate of food intake (Otto and Campbell, 1977). In well-fed animals, the stationary zonc is ncar the head, while in poorly fed animals it is near the middle of the body column. Hence, by reducing the food intake suddenly and severely, a neuron destined to be displaced in to the foot can change directions and end up in the head.

Thus, there is nothing truly fixed about the displacement destiny of a neuron, and experimental manipulation can change both the final location and the phenotype of a neuron. The simplest view is that the differentiated state of many neurons in hydra is only metastable and changes with alterations in the environment, in this case the regional position of a neuron.

\section{A position-dependent process is not sufficient to explain conversion}

The $\mathrm{FLI}^{+}$and $\mathrm{VLI}^{+}$subsets of neurons, which are known to be nonoverlapping subsets (Grimmelikhuijzen, 1983), have similar distributions in the hcad. Both subsets consist primarily of ganglion cells and are found along the entire length of the tentacles. Because a sizeable fraction of the neurons in the tentacles arise by displacement of neurons from the body column, the question arises as to how an $\mathrm{FLI}^{-} \mathrm{VLI}^{-}$neuron differentiates to become a member of one of the two subsets, or a member of an as yet undefined subset. As both have the same distribution, a position-dependent mechanism will not distinguish between the two subsets. An additional mechanism is required.

A simple explanation would be that the neurons were determined to become, for example, $\mathrm{FLI}^{+}$, in the body column before displacement onto the tentacle. The above-described ability of a neuron to undergo unexpected differentiations corresponding to experimentally induced changes in location makes this explanation unlikely.

A plausible mechanism that would influence an $\mathrm{FLI}^{-} \mathrm{VLI}^{-}$ ncuron in onc or the other direction is based on lateral inhibition. An example consistent with such a mechanism is the regular spacing, and the results of perturbation of the regular spacing, observed for dopaminergic cells in the developing frog retina (Reh and Tully, 1986). The possibility of lateral inhibition influencing phenotype decision is under investigation.

\section{References}

Alley KE, Barnes MD (1983) Birth dates of trigemminal motorneurons and metamorphic reorganization of the jaw myoneural system in frogs. J Comp Neurol 218:395-405.

Bode PM, Bode HR (1980) Formation of pattern in regenerating tissue pieces of Hydra attenuata. I. Head-body proportion regulation. Am Zool 78:484-496.

Bode H, Dunne J, Heimfeld S, Huang L, Javois L, Koizumi O, Yaross M (1986) Transdifferentiation occurs continuously in adult hydra. Curr Top Dev Biol 20:257-280.

Bode HR, Heimfeld S, Koizumi O, Littlefield CL, Yaross MS (1988) Maintenance and regeneration of the nerve net in hydra. Am Zool 28:1053-1063.
Campbell RD (1967a) Tissue dynamics of steady state growth in Hydra littoralis. I. Patterns of cell division. Dev Biol 15:487-502.

Campbell RD (1967b) Tissue dynamics of steady state growth in $H y$ dra littoralis. II. Patterns of tissue movement. J Morphol 121:19-28.

Campbell RD, David CN (1974) Cell cycle kinetics and development in Hydra attenuata. II. Interstitial cells. J Cell Sci 16:349-358.

Copenhaver PF, Taghert PH (1988) Position-dependent expression of peptidergic phenotype in post-migratory neurons of the insect enteric nervous system. Soc Neurosci Abstr 14:770.

Copenhaver PF, Taghert PH (1989) Development of the enteric nervous system in the moth. II. Stereotyped cell migration precedes the differentiation of embryonic nerves. Dev Biol 131:85-101.

Coulombe JN, Bronner-Fraser M (1986) Cholinergic neurones acquire adrenergic transmitters when transplanted into an embryo. Nature 324:569-572.

Cummings SG, Bode HR (1984) Head regeneration and polarity reversal in Hydra attenuata can occur in the absence of DNA synthesis. Rouxs Arch Dev Biol 194:79-86.

David CN, Campbell RD (1972) Cell cycle kinetics and development of Hydra attenuata. I. Epithelial cells. J Cell Sci 11:557-568.

David CN, Gierer A (1974) Cell cycle kinetics and development of Hydra attenuata. III. Nerve and nematocyte differentiation. J Cell Sci 16:359-375.

David C, Murphy S (1977) Characterization of interstitial stem cells in hydra by cloning. Dev Biol 58:372-383.

Davis LE (1972) Ultrastructural evidence for the presence of nerve cells in the gastrodermis of Hydra. Z Zellforsch 123:1-17.

Diehl FA, Burnett AL (1964) The role of interstitial cells in the maintenance of hydra. I. Specific destruction of interstitial cells in normal, asexual and non-budding animals. J Exp Zool 155:253-259.

Dunne JF, Javois LC, Huang LW, Bode HR (1985) A subset of cells in the nerve net of Hydra oligactis defined by a monoclonal antibody: its arrangement and development. Dev Biol 109:41-53.

Epp L, Tardent P (1978) The distribution of nerve cells in Hydra attenuata Pall. Wilhelm Rouxs Arch 185:185-193.

Grimmelikhuijzen CJP (1983) Coexistence of neuropeptides in hydra. Neuroscience 9:837-845.

Grimmelikhuijzen CJP, Sundler F, Rehfeld JF (1980) Gastrin/CCKlike immunoreactivity in the nervous system of coelenterates. Histochemistry 69:61-68.

Grimmelikhuijzen CJP, Balfe A, Emson PC, Powell D, Sundler F (1981a) Substance P-like immunoreactivity in the nervous system of hydra. Histochemistry 71:325-333.

Grimmelikhuijzen CJP, Carraway RE, Rokaeus A, Sundler F (1981 b) Neurotensin-like immunoreactivity in the nervous system of hydra. Histochemistry 72:199-209.

Grimmelikhuijzen CJP, Dockray GJ, Yanaihara N (1981c) Bombesinlike immunoreactivity in the nervous system of hydra. Histochemistry 73:171-180.

Grimmelikhuijzen CJP, Diedrickx K, Boer GJ (1982a) Oxytocin/vasopressin-like immunoreactivity is present in the nervous system of hydra. Neuroscience 7:3191-3199.

Grimmelikhuijzen CJP, Dockray GJ, Schot LPC (1982b) FMRFamide-like immunoreactivity in the nervous system of hydra. Histochemistry 73:499-508.

Hadzi J (1909) Uber das Nervensystem von Hydra. Arb Zool Inst Univ Wien 17:225-268.

Heimfeld S, Bode HR (1984) Interstitial cell migration in Hydra attenuata. II. Selective migration of nerve cell precursors as the basis for position-dependent nerve cell differentiation. Dev Biol 105:1017.

Heimfeld S, Bode HR (1985) Growth regulation of the interstitial cell population in hydra. I. Evidence for global control by nerve cells in the head. Dev Biol 110:297-307.

Hicklin J, Wolpert L (1973) Positional information and pattern regulation in Hydra: the effect of radiation. J Embryol Exp Morphol 30: 741-752.

Katz DM, Markey KA, Goldsmith M, Black IB (1983) Expression of catecholaminergic characters by primary sensory neurons in the normal adult rat in vivo. Proc Natl Acad Sci USA 80:3526-3530.

Kinnamon JC, Westfall JA (1982) Types of neurons and synaptic connections at hypostome-tentacle junctions in hydra. $J$ Morphol 173:119-128.

Koizumi O, Bode HR (1986) Plasticity in the nervous system of adult hydra. I. The position-dependent expression of FRMFamide-like immunoreactivity. Dev Biol 116:407-421. 
Koizumi O, Heimfeld S, Bode IIR (1988) Plasticity in the nervous system of adult hydra. II. Conversion of ganglion cells of the body column into epidermal sensory cells of the hypostome. Dev Biol 129: 358-371.

Landis SC, Keefe D (1983) Evidence for neurotransmitter plasticity in vivo: developmental changes in properties of cholinergic sympathetic neurons. Devel Biol 98:349-372.

Lentz TL, Barnett R (1965) Fine structure of the nervous system of Hydra. Am Zool 5:341-356.

Littlefield CL, Bode HR (1986) Germ cells in Hydra oligactis males II. Evidence for a subpopulation of interstitial stem cells whose differentiation is limited to sperm production. Dev Biol 116:381-386.

Loer CM, Kristan WB (1989a) Peripheral target choice by homologous neurons during embryogenesis of the medicinal leech. I. Segmentspecific preferences of Retzius cells. J Neurosci 9:513-527.

Loer CM, Kristan WB (1989b) Peripheral target choice by homologous neurons during embryogenesis of the medicinal leech. II. Innervation of ectopic reproductive tissue by nonreproductive Retzius cells. J Neurosci 9:528-538.

Marcum BA, Campbell RD (1978) Development of hydra lacking nerve and interstitial cells. J Cell Sci 29:17-33

Otto JJ, Campbell RD (1977) Tissue economics of hydra: regulation of cell cycle, animal size and development by controlled feeding rates. J Cell Sci 28:117-132.

Patterson PH, Chun LLY (1977) The induction of acetylcholine synthesis in primary cultures of dissociated sympathetic neurons. I. Effects of conditioned medium. Dev Biol 56:263-280.
Reh TA, Tully T (1986) Regulation of tyrosine hydroxylase-containing amacrine cell number in larval frog retina. Dev Biol 114:463469.

Sacks PG, Davis LE (1979) Production of nerveless Hydra attenuata by hydroxyurea treatments. J Cell Sci 37:189-203.

Schotzinger RJ, Landis S (1988) Cholinergic phenotype developed by noradrenergic sympathetic neurons after innervation of a novel cholinergic target in vivo. Nature 335:637-639.

Sulston JE, Horvitz HR (1977) Postembryonic cell lineages of the nematode Caenorhabditis elegans. Dev Biol 56:110-146.

Thorn RS, Truman JW (1989) Sex-specific neuronal respecification during the metamorphosis of the genital segments of the tobacco hornworm moth Manduca sexta. J Comp Neurol 284:489-503.

Westfall JA, Kinnamon JC (1978) A secondary sensory-motor-interneuron with neurosecretory granules in Hydra. J Neurocytol 7:365379.

Westfall JA, Rogers RA (1990) A combined high-voltage and scanning electron microscope studey of 2 types of sensory cells dissociated from the gastrodermis of hydra. J Submicrosc Cytol Pathol 22:185190.

Yaross MS, Westerfield J, Javois LC, Bode HR (1986) Nerve cells in hydra: monoclonal antibodies identify two lineages with distinct mechanisms for their incorporation into head tissue. Dev Biol 114: 225-237. 